\title{
КОНЦЕПТУАЛЬНІ ПИТАННЯ РОЗРОБКИ СТАНДАРТІВ ВИЩОЇ ОСВІТИ ДЛЯ ПІДГОТОВКИ ЛІКАРІВ
}

\author{
Ю. В. Вороненко, Ю. П. Вдовиченко, О. П. Мінцер, О. М. Вернер, В. В. Краснов
}

Національна медична академія післядипломної освіти імені П. Л. Шупика МОЗ України

\section{CONCEPTUAL ISSUES OF DEVELOPMENT OF STANDARDS OF HIGHER EDUCATION FOR DOCTORS' TRAINING}

\author{
Yu. V. Voronenko, Yu. P. Vdovychenko, O. P. Mintser, O. M. Verner, V. V. Krasnov \\ National Medical Academy of Post-Graduate Education by P. L. Shupyk of MPH of Ukraine
}

\begin{abstract}
У процесі удосконалення системи медичної освіти виникає багато невирішених питань, основні 3 яких пов'язані зі специфікою підготовки лікаря та історично побудованою системою його підготовки. В статті розглядаються деякі проблемні напрямки, вирішення яких повинно значно покращити якість формування фахівців-медиків.
\end{abstract}

In the process of improvement of medical education system there are occured a lot of unsolved questions, the main of which are connected with the specificity of doctor's training and historically built the system of his training. The article adduces some problem directions, solving of which should considerably improve the quality of forming of doctors-professionals.

Вступ. На даний час головним завданням європейської вищої освіти є збереження й забезпечення необхідної якості професійної підготовки фахівців і пошук механізмів іï підвищення. У 1995 р. ЮНЕСКО був розроблений Програмний документ "Реформа й розвиток вищої освіти", частина змісту якого присвячена якості освіти. У ньому, зокрема, підкреслюється ряд аспектів освітньої діяльності, які найбільш істотно впливають на якість вищої освіти: а) якість персоналу, що гарантується високою академічною кваліфікацією викладачів і наукових співробітників ВНЗ; б) якість освітніх програм, що забезпечується поєднанням викладання й досліджень; в) якість підготовки студентів; г) якість інфраструктури тощо.

Приєднання України до Європейського освітнього простору вимагає органічної інтеграції національної системи освіти у світову. У медичній галузі на міжнародному рівні постійно ініціюється діяльність щодо забезпечення якості освіти. Серед багатьох чинників одним 3 найважливіших $є$ впровадження освітніх стандартів і створення систем для визнання й акредитації вищих навчальних закладів і програм.

Саме стандарти вищої освіти $є$ одним $з$ основних інструментів забезпечення однакових вимог до результатів навчання й, як наслідок, вагомою складовою частиною системи забезпечення якості підготовки фахівців [1].
Дослідження принципів розробки змісту державних освітніх стандартів для післядипломної медичної освіти пов'язані з розв'язанням ряду концептуальних питань, обумовлених специфікою післядипломної медичної освіти, а також тим, що основні принципи побудови державних освітніх стандартів розроблені для моделі дипломної освіти [2]. Ці проблемні питання можна відобразити таким чином:

1. Підготовка магістра на післядипломній фазі має свої відмінності в порівнянні з дипломною фазою.

2. Формат структури державних освітніх стандартів не дає можливості відображати якісний рівень формування компетенції залежно від рівня освіти.

3. Не існує конкретного визначення відмінності між освітньо-кваліфікаційними рівнями на концептуальному і формальному рівнях.

4. Ринок праці не в змозі сформувати й запропонувати системі освіти універсальну модель фахівця, на основі якої розробляються освітні стандарти.

5. Відсутні точно описані відмінності між “посадами” і “роботами", що значно ускладнює розробку компетенцій і точний опис посад, на які може претендувати молодий лікар.

6. Не існує чіткого поділу діяльності лікаря на фрагменти згідно з виробничими функціями, що визначені в структурі ОКХ.

Основна частина. Традиційно система підготовки фахівців в Україні грунтувалася на освітньо-ква-

() Ю. В. Вороненко, Ю. П. Вдовиченко, О. П. Мінцер та ін. 
ліфікаційних рівнях молодшого спеціаліста та спеціаліста. 3 інтеграцією до Європейської системи постала проблема введення принципів англо-саксонської моделі освіти, а саме рівнів бакалавра та магістра.

Проте зарубіжна модель підготовки лікаря “бакалавр - магістр - лікар резидент” напряму не транспонується на Українську модель, яка формувалася десятиліттями і до кінця минулого сторіччя набула гармонізованого, цілісного характеру у вигляді послідовності “спеціаліст - інтерн”.

Перше й основне питання, що поки не має свого однозначного трактування - хто такий магістр і на якій фазі медичної освіти його потрібно готувати на дипломній або післядипломній.

Якщо ініціювати модель, згідно 3 якою бакалавр та магістр навчаються на дипломному етапі, то тоді постає проблема, де може працювати бакалавр 3 медицини, якщо він не в змозі продовжити навчання в магістратурі. Це може означати додаткові 3-4 роки підготовки у стінах медичного університету.

Крім того, закінчену освіту лікар набуває після виходу з інтернатури. Таким чином, навіть після отримання диплома магістра на дипломній фазі (згідно 3 проектом нового закону про вищу освіту) молодий фахівець не може працювати за спеціальністю. Він повинен пройти ще навчання в інтернатурі, що традиційно відноситься до післядипломного етапу навчання. Але цей перехід - 3 дипломної до післядипломної фази супроводжується подальшим розділенням 4-х спеціальностей дипломної підготовки на більш ніж 30 спеціальностей в інтернатурі. Виникає питання, чи повинен, наприклад, лікар-неонатолог проходити магістратуру, якщо він їі вже закінчував на дипломній фазі як лікар-педіатр?

На сьогодні медицина має змішану систему підготовки - спеціаліст на дипломному рівні, інтерн на післядипломному, і паралельно з інтернатурою-можливість проходження магістратури з обраної спеціальності.

Якщо буде прийнята модель, згідно з якою магістр - це вже спеціалізація на післядипломному етапі, а дипломну фазу завершують бакалаври, то така модель знову відрізняється від Європейської.

Ще одна проблема полягає в наступному. Формат подання компетенцій не дає можливість відобразити їх якісні характеристики залежно від освітньо-кваліфікаційного рівня. Наприклад, і для спеціаліста і для магістра (а в найближчому часі для магістра та інтерна) є компетенція, пов'язана $з$ виокремленням та фіксацією провідного клінічного симптому або синдрому. Перелік симптомів і синдромів за кількістю може відрізнятися, але є деяка сукупність, що збігається. За якістю володіння даною компетенцією магістр повинен бути вище спеціаліста. Тобто в даному прикладі магістр повинен з більшою ймовірністю встановити правильний діагноз у нестандартних умовах навколишнього середовища, специфічних індивідуальних особливостей пацієнта, з урахуванням ймовірності помилок інструментальних методів дослідження, нашарування супутніх захворювань тощо. Таким чином, відмінність магістра та спеціаліста полягає не в наборі компетенцій, а в ступені їх розвитку, тобто в кваліфікаційному рівні. Вище цей рівень повинен бути у магістра, але формат опису державних освітніх стандартів не дає можливості в повному обсязі відображати цей момент.

Наступна проблема - визначення точних відмінностей між освітньо-кваліфікаційними рівнями на концептуальному і формальному рівнях.

У європейських країнах в останні роки у магістратурі робиться наголос на розвиток найбільш цінних транспрофесійних знань, навичок і умінь, власник яких може мислити і діяти комплексно, охоплюючи не тільки свою вузьку предметну сферу, а й медичну професію в цілому. Крім того, в магістратурі триває поглиблення професійних знань, а у спеціаліста завжди був акцент на потужну теоретичну підготовку 3 хорошою вузькою спеціалізацією.

У свою чергу, в офіційних державних документах для магістра визначена діяльність 3 виконання “професійних завдань та обов' язків (робіт) інноваційного характеру”, що відсутня у бакалавра і спеціаліста. Тобто бакалавр готується до кваліфікованого виконання традиційних професійних завдань і функцій за допомогою стандартних технологій, а магістр готується до вирішення нестандартних завдань за допомогою інноваційних i, якщо потрібно, самостійно створених ним технологій та методик. Також він готується до комплексного управління ресурсами, процесами і командами, до консультування керівництва щодо різних аспектів діяльності, до проведення науково-дослідних робіт 3 виявлення проблем та розвитку у своїй професійній галузі тощо.

У європейських країнах здобуття наукового ступеня можливе тільки після завершення магістратури. Наше законодавство в боротьбі за право кожного на кар'єрне зростання залишає подібне право для всіх, хто завершив освіту.

Слід назвати ще одну проблему. У методичних документах МОН молодьспорту України з розробки освітніх стандартів чітко зазначено, що останні 
повинні розроблятися тільки на основі кваліфікаційних характеристик професій працівників [2].

Іншими словами, вимоги до системи освіти щодо підготовки фахівців повинні формуватися з боку професії. Тобто ринок повинен сформувати свої чіткі вимоги до того “продукту”, що буде створений системою освіти. У свою чергу, система освіти, відповідно до міжнародних вимог до побудови систем якості, повинна постійно проводити моніторинг задоволеності споживача (ринку) здійсненими освітніми послугами.

Проблема полягає в тому, що ринок не в змозі сформувати й запропонувати системі освіти універсальну модель фахівця. Як наслідок, не маючи замовлення з ринку, система освіти не в змозі побудувати чіткі освітні цілі й результати навчання, які повинні відображатися в освітніх стандартах і відповідати запитам майбутніх споживачів.

Вимушено формуючи освітні стандарти у своєму розумінні, система освіти випускає "продукт" (фахівців), що не знаходить прямого попиту на ринку праці. Роботодавець, прагнучи одержати фахівця потрібного рівня, витрачає досить велику кількість ресурсів на “донавчання” молодих працівників.

Надалі фахівці, отримуючи додаткову освіту у процесі роботи, настільки далеко віддаляються від форм і термінології навчальних систем, що не в змозі сформувати вимоги до системи освіти.

Утворюється замкнуте коло: ринок не в змозі сформулювати чітке замовлення в систему освіти, а система освіти випускає “продукт”, що вимагає подальшої серйозної доробки.

Виникає питання: хто з боку ринку повинен і може сформулювати модель фахівця. Вважається, що в системі освіти споживач є комплексним. У це об'єднання входить, в основному: держава, суспільство, роботодавець, той, кого навчають. Цілком логічно, що й у групу експертів повинні входити представники цих груп.

За кордоном у створенні стандартів вищої медичної освіти беруть участь представники державних структур, медичних асоціацій, великих комерційних організацій, провідних університетів.

Як показує наш досвід, саме участь всіх категорій споживачів у формуванні моделі фахівця надає можливість отримати якісну модель результату його підготовки.

Ще одну грань цієї проблеми можна побачити при визначенні первинних посад та професійних робіт за державним класифікатором, яким може відповідати випускник магістратури. Відсутність точно описаних відмінностей між посадами і роботами значно ускладнює складання компетенцій і точний опис посад, на які може претендувати молодий лікар.

Ще одна проблема - чіткий розподіл інтегральної діяльності лікаря на фрагменти відповідно до виробничих функцій, які визначені в структурі ОКХ. Для того щоб лікар досяг основної мети своєї діяльності, яка полягає в постановці діагнозу і проведенні лікування, він виконує величезну кількість інтелектуальної, технологічної та евристичної роботи, проте поділяти ії на фрагменти, які відповідають компетенціям згідно з дослідницькою, проектувальною, організаційною, управлінською, технологічною, контрольною, прогностичною та технічною функціями не завжди видається доцільним.

Крім того, якщо ми говоримо про освітній стандарт як про цілісну модель фахівця, представлену у вигляді опису компетенцій, то особливу складність представляє чітка класифікація цих компетенцій відповідно до видів типових задач діяльності (професійна, соціально-виробнича, соціально-побутова), видів умінь (предметно-практичне, предметно-розумове, знаково-практичне, знаково-розумове), класів задач діяльності (стереотипна, діагностична, евристична), як того потребує формат стандарту.

Висновки: 1. Організація післядипломної медичної освіти з урахуванням компетенцій являє собою недостатньо відпрацьований напрямок у вітчизняній охороні здоров’я. Подібні нововведення вимагають не просто переробки навчального плану, а необхідне узгодження всіх навчальних процедур і забезпечення наступності навчання на всіх фазах медичної освіти. Більше того, при формалізації напрямку компетенцій виникає питання про готовність педагогічних кадрів і кадрів практичної охорони здоров'я до функціонування в практичному полі компетенцій.

2. Вважаємо надзвичайно важливим створення освітніх моделей випускників вищих навчальних закладів у форматі державних освітніх стандартів, але разом 3 тим наголошуємо про специфіку медичної галузі та важливість розробки комплексного підходу, який би враховував всі аспекти підготовки медиків на найвищому, якісному рівні.

3. Для забезпечення впровадження принципів компетенції в післядипломну медичну освіту :

- має змінитися вся педагогічна система професійної медичної школи шляхом переходу до нового типу навчання й виховання;

- перехід до освіти, що базується на вимірі компетенції, потребує певного процесу осмислення, досліджень, розробок і прийняття науково обгрунтованих й адміністративно зважених рішень; 
Матеріали Всеукраїнської навчально-наукової конференції, присвяченої 55-річчю Тернопільського державного медичного університету імені І. Я. Горбачевського, “Впровадження нових технологій за кредитно-модульної системи організації навчального процесу у ВМ(Ф)НЗ III-IV рівнів акредитації”

- у реалізації цього процесу потрібна опора на розвинену психолого-педагогічну теорію або комплекс теорій;

\section{Література}

1. Управление качеством подготовки специалистов : программно-целевой подход (на примере высшего и послевузовского медицинского образования) : монография / [В. Н. Казаков, Н. А. Селезнева, А. Н. Талалаенко и др.]. Москва-Донецк : Исследовательский центр проблем качества подготовки специалистов, Донецкий государственный медицинский университет, 2003. - 215 с.
- без серйозних інвестицій у медичну освіту перейти до нової моделі організації процесу навчання неможливо.

2. Комплекс нормативних документів для розроблення складових системи галузевих стандартів вищої освіти [Електронний ресурс] / Лист Міністерства освіти і науки України від 31.07.2008 p. № 1/9-484 Головам робочих груп МОН України з розроблення галузевих стандартів вищої освіти та головам науково-методичних комісій МОН України. 73 c. - Режим доступу: elib.crimea.edu/zakon/list484.pdf. 